University of Nebraska - Lincoln

DigitalCommons@University of Nebraska - Lincoln

To Improve the Academy

Professional and Organizational Development Network in Higher Education

1997

\title{
Helping Faculty Design Assignment-Centered Courses
}

Barbara E. Walvoord

John R. Breihan

Follow this and additional works at: https://digitalcommons.unl.edu/podimproveacad

Part of the Higher Education Administration Commons

Walvoord, Barbara E. and Breihan, John R., "Helping Faculty Design Assignment-Centered Courses" (1997). To Improve the Academy. 395.

https://digitalcommons.unl.edu/podimproveacad/395

This Article is brought to you for free and open access by the Professional and Organizational Development Network in Higher Education at DigitalCommons@University of Nebraska - Lincoln. It has been accepted for inclusion in To Improve the Academy by an authorized administrator of DigitalCommons@University of Nebraska - Lincoln. 
Walvoord, B. E., \& Breihan, J. R. (1997). Helping faculty design assignment-centered courses. In D. DeZure (Ed.), To Improve the Academy, Vol. 16 (pp. 349-372). Stillwater, OK: New Forums Press and the Professional and Organizational Development Network in Higher Education. Key Words: Faculty Development Programs, Instructional Improvement, Course Development, Active Learning.

\section{Helping Faculty Design Assignment-Centered Courses}

\section{Barbara E. Walvoord}

University of Notre Dame

\section{John R. Breihan}

Loyola College in Maryland

Faculty developers must help faculty shift from a teaching paradigm to a learning paradigm. Workshops that help faculty plan the "assignment-centered" course are a productive approach to that challenge. This article shows faculty developers how to plan and lead such a workshop. Research suggests that faculty often focus on content and coverage in their course planning. To combat this tendency, the workshop leads faculty through the course-planning process. In the workshop, faculty first develop learning objectives, then plan the assignments and exams that will both teach and test the essential skills and knowledge of the course. Then faculty choose and organize their instructional methods and the use of in-class and out-of-class time to maximize the development of the most important knowledge and skills. This approach contrasts with the text-lecture-coverage-centered course, in which the teacher concentrates first on the topics she or he will cover. The assignment-centered course is one of the strategies that research suggests will enhance students' critical thinking in higher education. 


\section{The Assignment-Centered Course}

Increasingly faculty developers are being called upon to help faculty shift from a teaching paradigm to a learning paradigm. Focusing on the assignment-centered course is one productive approach to that challenge. Research suggests that the assignment-centered course enhances students' critical thinking (Kurfiss, 1988).

In planning the assignment-centered course, instructors begin not by planning content and coverage, but by establishing what they most wants students to do by the end of the course. Then they construct assignments and exams that both teach and test the essential skills and knowledge of the course. They choose pedagogical strategies, and they use in-class and out-of-class time to ensure that students systematically learn and practice the skills necessary to succeed in those assignments and exams. When faculty adopt the assignment-centered approach from the first moments of the course-planning process, they can structure the course around a learning paradigm, address the "coverage" issue, and manage workload. Because this course-planning strategy contrasts with faculty's normal content-centered course planning, it makes sense to bring the course-planning process into the workshop.

We can illustrate the differences between the two approaches by contrasting the planning processes of two faculty members planning "Western Civilization," a one-semester general education history course for first-year students. Professor A begins her lecture/textbook/coverage-centered planning process by saying to herself, "In this course, I have to cover 1500 through the end of the Cold War." Then she divides the semester into sections, covering $1500-1800$ in the first six weeks, and so on. Professor B, who is "assignment-centered," begins his course planning by saying, "By the end of this course, I want my students to be able to construct arguments about debatable issues within the period 1500 through the end of the Cold War." Then he constructs the assignments and exams that will both teach and test what he wants students to learn. He plans the rest of the course to teach the information, concepts, and skills students will need to construct their arguments. This mode of course planning tends to draw Prof. B away from straight lecture to collaborative learning, active learning, 
and other strategies that help students build skills such as argumentation. Facts and coverage do not disappear, but they are organized around a focused set of learning goals. To plan an assignment-centered course is to move from "I must cover" to "They must learn."

Research suggests that the typical faculty planning process focuses heavily on content (Stark and Lattuca, 1997, p. 114). Typical faculty planning processes may not yield the kind of interactive teaching that research suggests will enhance students' critical thinking (Angelo, 1993; Chickering and Gamson, 1987) and that faculty development workshops often promote. It makes sense, then, to bring the course-planning process INTO the workshop.

Our goal in this article is to enable our readers to plan and lead a 1-2-day faculty workshop in which participants actually engage in planning a course of their own that is "assignment-centered." Our experience suggests that a major stumbling block for faculty will be their sense that they must use class time to "cover" material. Thus, in this article we also devote considerable attention to a model by which faculty can think about how they structure and use both in-class time and students' study time.

We will use as a model a workshop frequently offered by Walvoord. In her workshops, she uses a "case" developed by Breihan, Professor of History at Loyola College in Baltimore. Breihan, who also has led faculty-development workshops and has served as co-director of his college's cross-curricular writing program, describes how a standard first-year Western Civilization course might be structured along the "assignment-centered" lines we advocate. In this essay we present or summarize some of the materials on Breihan's course; for more detailed explanation, syllabus, assignments, etc., consult our website: www.dev.loyola.edu| jbreihan.

You may duplicate and use for workshops any materials presented here or on our website. 


\section{How to Lead the Workshop}

-Barbara E. Walvoord

\section{Titling and Advertising the Workshop}

I never use the term "assignment-centered" in the workshop title because it means little to faculty until the concept has been explained to them. I usually call the workshop "Teaching the Thinking of the Discipline" or "Designing Courses for..." or "Getting Students Involved in Learning." In the title or the workshop description, make clear that in the workshop faculty will design their own courses. Invite participants to bring a current syllabus and key assignments if they have them.

\section{Workshop Step 1: Articulate Participants' Concerns and Objectives}

A study that I and my colleagues recently completed (Walvoord et al., 1997) suggests that faculty members come to workshops with their own goals and concerns strongly in mind. Thus the first step in the workshop is to ask everyone (or, in a large workshop, a sample of participants) to name issues they would most like to see addressed in the workshop. Participants typically mention grading and responding, assignment design, student motivation, handling the paper load, getting good class discussions, etc. I list these on a screen, blackboard, or newsprint sheets so I can continue to refer to them throughout the workshop. Thus I convey that the approach I am about to explain integrates current faculty concerns.

Next, and still without mentioning the word "assignment-centered," I ask each participant to select one of his/her own courses on which to focus during the workshop. Each participant then lists, in 7 or 8 minutes, the 3-5 things he or she most wants students to be able to do at the end of that course. I urge participants to avoid vague words such as "know" or "understand" and passive voice verbs such as "be exposed to." I encourage verbs such as "define," "argue," "describe," "analyze," "solve," and "create." I show an example of what Breihan wants from his students at the end of his required General Education Western Civilization course for first-year students: 
Students should be able to:

(A) define, describe, and analyze important historical events, people, and concepts

(B) use this information to formulate arguments in which they state a position, back it with accurate and specific evidence, and answer counterarguments against it.

I give examples from other disciplines. A mathematician may write, "I want my students to solve [certain kinds of] mathematical problems and to be able to explain what they did and why they did it." Faculty in client-oriented disciplines such as nursing may write, "I want my students to observe clients effectively, to identify problems, and to find reasonable solutions." Literature faculty will write, "I want my students to analyze literature using the strategies common to literary studies," or "I want my students to enjoy literature."

After a 3-minute period when people call out items from their lists, I point out that no one has written, "I want my students to memorize 4,275 facts about my discipline." Instead, they have listed disciplinespecific abilities of what might be called "critical thinking" or "higherorder reasoning." Basic information, concepts, and procedures ARE important, but most faculty want students to USE that basic material for higher-order thinking. This step take 20-40 minutes.

\section{Workshop Step 2: Introduce Methods for Interactive Teaching}

The next step is to give participants 3 minutes to list what they believe are the best teaching methods to achieve the learning objectives they have listed earlier. They compare their own lists to my research-based list (see Figure 1).

\section{Workshop Step 3: Acknowledge the Difficulties of Interac- tive Teaching}

Often, faculty members' initial response to this list is to feel overwhelmed and inadequate. Sometimes, to loosen up the group and to demonstrate that I take their difficulties seriously, I ask each person to write privately on a sheet of scratch paper one reason why it is hard for them to use these strategies. Then I ask them to ball up that paper 
and throw it across to the other half of the room. This of course results in lots of laughter as balls go awry and I or others must scoop them up and redirect them. Then each person unrolls the ball that she or he has caught and reads it. Typically, people have written, "Class is too large" or "Students expect me to lecture" or "Seats in my classroom are bolted to the floor" or, "don't have the skills to do this" or my favorite comment of all time, " hate to change." I make a list of the comments on newsprint and then tape the newsprint to the wall to demonstrate that the workshop will help faculty to deal realistically with these difficulties. Then I refer to them again periodically throughout the workshop. This step takes 15 or 20 minutes. In a workshop of only one day, I may omit it in favor of a 2-minute acknowledgment of some of these difficulties.

\section{Workshop Step 4: Ilustrate the "Assignment-Centered" Course}

I now call participants' attention to Item 10 on my list (Figure 1), which suggests the "assignment-centered" course. I give them three

\section{FIGURE 1 \\ Best Teaching Methods for Critical Thinking and Higher-Order Reasoning in Higher Education: What the Research Suggests}

1. Have students write about and discuss what they are leaming

2. Encourage faculty-student contact, in and out of class

3. Get students working with one another on substantive tasks, in and out of class

4. Give prompt and frequent feedback to students about their progress

5. Communicate high expectations

6. Make standards and grading criteria explicit

7. Help students to achieve those expectations and criteria

8. Respect diverse talents and ways of learning

9. Use problems, questions, or issues, not merely content coverage, as points of entry into the subject and as source of motivation for sustained inquiry

10. Make courses assignment-contered course rather than the text/lecture/coveragecentered. Then focus on helping students successfully complete the assignments.

Sources: Angelo, 1993; Chickering and Gamson, 1987; Kurfiss, 1988. 
reasons for being interested in the concept: (1) research suggests it will enhance student learning; (2) the "assignment-centered" course can integrate other good teaching strategies; and (3) it can help them deal with workload.

To lay the groundwork for the assignment-centered course, I present a hypothetical course that is text/lecture/coverage-centered. The hypothetical professor might first begin to think about the course when her department head says, "Jane, will you teach 'Western Civ' this fall?" She next checks, or composes, the catalogue description, which tells the content of the course: Western Civilization from 1500 to the end of the Cold War, emphasizing such-and-such themes. Now she lays out the 15 weeks (see Figure 2), saying to herself:

Let's see. I'd like to use Burke and Paine, Marx, Lafore, and Heart of Darkness in addition to the textbook. I'll cover 1500 to the French Revolution in six weeks and get through the French Revolution by midterm. Then in the second half of the course, I'll cover 1800 to the present.

I ask the group, "What is the subject of these sentences?" Answer: "I". The most common verb? Answer: "will cover." This teacher is already well launched on the coverage-centered model. Next, she will compose her syllabus. It will go something like this:

\begin{tabular}{|c|c|c|c|}
\hline \multicolumn{4}{|c|}{$\begin{array}{c}\text { FIGURE } 2 \\
\text { Text-Lecture-Coverage-Centered Course Skeleton for } \\
\text { Western Civilization (1500-present) }\end{array}$} \\
\hline Week & Tople & Week & Topic \\
\hline 1 & Renaissance/Reformation & 8 & Industrial Revolution \\
\hline 2 & 17th-Contury Crisis & 9 & Marx, Communist Manifesto \\
\hline 3 & Absolutism & 10 & Imperialism \\
\hline 4 & Age of Reason & 11 & Conrad, Heart of Darkness \\
\hline 5 & French Revolution & 12 & World War I \\
\hline 6 & $\begin{array}{l}\text { Burke, Reflections, and Paine, } \\
\text { Rights of Man }\end{array}$ & 13 & Lafore, Long Fuse \\
\hline 7 & MIDTERM & & $\begin{array}{l}\text { World War II/Cold War } \\
\text { FINAL }\end{array}$ \\
\hline
\end{tabular}


Tues., Sept. 5: Social and religious background of the Renaissance and Reformation. Read ch. 1 and 2 in textbook.

Thurs., Sept. 7: Economic and political background of the Renaissance and Reformation. Read ch. 3 in textbook; Machiavelli handout.

"When students first see this syllabus," I ask the group, "what are they likely to assume will happen in the class?" Answer: "lecture." Thus the traditional course-planning process and the syllabus that results from it can trap both the faculty member and the students into the text/lecture/coverage-centered model.

Once the teacher has filled in the topics she has to "cover," she is likely to say to herself,

Let's see, I'll use essay tests at midterm and final, with questions on lecture, textbook, and supplementary readings. The midterm will cover 1500-1800. I'll have a "comprehensive" final, covering all the course material, but I'll weight it in favor of 1800 to the present. And I'll assign a term paper due near the end of the course. Students can choose which of the supplementary readings they'll cover in their term papers.

In this text/lecture/coverage-centered planning process, the tests and papers are added on at the end, and their implied role is to test coverage.

Asked in a workshop what she wants students to be able to do at the end of the course, this faculty member lists goals similar to Breihan's - that is, she not only wants students to describe events but also to analyze and argue. Will her current exams and term paper likely elicit coherent arguments with full evidence and answers to counter arguments? Participants often volunteer that essay exams may be merely what one teacher called "fact dumps." Research indicates, I tell participants, that many students view school reading as a collection of discrete facts to be memorized and regurgitated on tests. Further, I remind the group, some students have taken essay exams that were graded in this way: the teacher went through the student's answer, placing a check mark next to every fact or idea that would "count," and the student's score was the total of the check marks. What is the smart person's way of taking such a test? Someone will say, "fact dump." Moreover, if the students see the exam question for the first time when they walk into the class and then have 20 minutes or 50 
minutes to write a cogent argument, what is likely to come out? I ask participants, "What comes out when you yourself, as a faculty member, pose yourself a task or question for the first time-say for a research proposal or journal article -and write about it for 50 minutes. Is it cogent, tightly argued, thoroughly logical?"

The term paper, too, is likely to be a disappointment. Participants will probably predict that many term papers will be cut-and-paste pastiches of library sources. Schwegler and Shamoon (1982) asked students in a variety of disciplines what they thought a term paper was and how they did one. Students described term papers as gathering and displaying information. Professors, when asked what they thought a term paper should be, responded with verbs like "analyze" and "argue." But "I'm not in the habit of developing arguments," said a student I interviewed in a Western Civ course. "In high school we took the answers straight from the book." A lecture-based class with a term paper tacked onto the end is not likely to elicit cogent arguments from that student.

In contrast, what would an "assignment-centered" course look like, and how might it help to address the problems we have noted? The assignment-centered course begins by stating not what the teacher must cover, but what the students will be asked to do. Then insert the major tests and assignments in the week in which they are due. (I define "major" as those tests and assignments on which the majority of the student's grade will be calculated, and on which the teacher would stake his or her reputation for achieving the most important learning in the course). At this stage, don't list all the smaller, preparatory tests, quizzes, and so on. Faculty need to see the course in its bare-bones outline, with just the major tests and assignments. Then the teacher can ask, "Are my major assignments and tests likely to elicit the kind of learning I most want?" As an example, I use an assignment-centered course skeleton composed by John Breihan (see Figure 3). You might use your own example. Here is Breihan's explanation of his assignment-centered course. 


\section{My Assignment-Centered Course Plan for Western Civ}

My course, like the hypothetical text/lecture/coverage/centered course presented earlier, proceeds in chronological order. Having students master factual material remains one of my two stated course goals. But unlike the hypothetical course, my essay tests, designed to elicit higher-order thinking, are spaced more evenly through the semester. Because each has the same format, students have the opportunity to improve their level of performance by carrying over their experience on one test to the next.

I hand out and discuss the "essay" topics in advance of the "test" date, so that students can go through their notes and readings to frame arguments and to locate the facts that they think will best contribute to their arguments. Students must write a draft of their essays in class

\section{FIGURE 3}

Breihan's Assignment-Centered Course Skeleton for Western Civilization (1500-end of Cold War)

By the end of the course, I want my students to: [see Breihan's goals, listed earlier]

\begin{tabular}{|c|c|c|c|}
\hline Week & Major assignment & Week & Major assignment \\
\hline 1 & & 8 & \\
\hline 2 & & 9 & \\
\hline 3 & & 10 & \\
\hline 4 & & 11 & $\begin{array}{l}\text { In-dass essay on Industrial } \\
\text { Rev./Imperialism; revision optional }\end{array}$ \\
\hline 5 & & 12 & \\
\hline 6 & $\begin{array}{l}\text { In-class essay on Age of } \\
\text { Reason/French Revolution, later } \\
\text { revised after teacher comment }\end{array}$ & 13 & \\
\hline \multirow[t]{2}{*}{7} & & 14 & \\
\hline & & 15 & $\begin{array}{l}\text { In-dass essay on World War } \\
\text { IMl/Cold War (given in final exam } \\
\text { period) }\end{array}$ \\
\hline
\end{tabular}


without notes. The in-class format discourages students from another traditional counterproductive technique, copying material directly from their textbooks. For the first essay of the semester, I offer comments on the in-class drafts, and students then revise those drafts at home for their final grade. For the second essay, revision is optional. For the third, written in the final exam period, revision is not possible.

Notice that, in comparison with the hypothetical Western Civ course, I assign no formal term paper. Sometimes it is better to concentrate on fewer well-conceived and well-guided learning experiences than to proliferate poorly-designed and poorly-guided papers and exams.

The assignments in this course skeleton are by no means the only pieces of writing students produce in the course. There are numerous short writings by which students respond to readings and actually learn the skills needed to make effective arguments. More on these later. For now, we want to concentrate on the course skeleton.

\section{Workshop Step 5: Participants Construct Course Skele- tons}

-Barbara Walvoord

After reviewing Breihan's course skeleton, which takes 15-30 minutes, I show several other course skeletons from various disciplines (included on our website), and participants discuss: (1) whether the major tests and assignments are best structured so as to elicit the kind of learning the teacher most wants and (2) whether the number and distribution of major tests and assignments are sustainable in terms of workload. When such problems are pointed out, I ask participants in small groups to generate suggestions for improvement in the course. This takes 15-30 minutes.

Next, I ask participants to work alone or with others for 20-30 minutes on constructing their own course skeletons and posing the two questions. I remind them that the skeleton should contain only the major, graded tests and assignments, not every smaller assignment or quiz. I keep myself available for consultation. 


\section{Workshop Step 6: How to Help Students Learn What}

\section{They Need for Their Tests and Assignments}

When we reconvene, I make the point that in the assignment-centered model the whole course is planned to give students the knowledge and skills they need if they are to do well on the major tests and assignments.

To illustrate, I put Breihan's course skeleton (see Figure 3) back on the screen and ask whether, according to the research we have reviewed earlier in the workshop, lecturing each class day is the best way to prepare students to write the first argumentative essay in week 6. The answer is "no."Well then, what IS the best method? I tell faculty that they should not just pick teaching strategies at random from my list (see Figure 1), nor should they seize every neat idea they hear"oh, yeah, let's do journals." Rather, they need to construct interactive learning strategies from a clear idea of what THEIR students MOST NEED TO LEARN in order to do well on the major tests and assignments.

To illustrate how a teacher can plan interactive learning strategies, I return to Breihan's case. His planning begins by examining his central assignments and tests. As an example, I show participants this short summary of an argumentative essay assignment that Breihan's students write in week 6, for his first unit, on The Age of Reason/French Revolution.

Though Edmund Burke and Thomas Paine did not directly answer to the question, "Was Louis XIV of France a good king for his times?" how WOULD they have answered it? With whom would you agree? Be sure to give evidence for your views and respond to counterarguments against them. [The actual assignment to students provides fuller detail.]

I ask participants to suggest what first-year students at THEIR institutions would need to learn if they were to write a successful answer. Typically, faculty mention things like 'facts about Louis' reign" and "understanding how to find and structure counterarguments." (Breihan's own list is on our website, and in Walvoord and Anderson,in-press.) Then I give participants 7-10 minutes to look at 
the first assignment or test from their own course skeleton and to generate a similar list.

Then, working from the list that participants made for Breihan's Burke/Paine/Louis assignment, I ask participants in small groups, in 10 minutes, to generate ideas about what Breihan could do during the first six weeks to help his students learn what they need to know.

As we share these ideas in the larger group, the issue of content coverage is sure to come up. Faculty will say that students can't do well on this assignment unless they know a lot about Louis, his era, and the philosophies of Burke and Paine. How can one cover all this and still have time for interactive discussion in class? Faculty in scientific and technical fields are sure to say that their courses are much different from history, where one can discuss and argue. Their students are preparing for board exams, for medical school, for chem 102 , and they need to cover all the required material. Also, faculty will be worried that students are not prepared for class discussion or that interactive teaching wastes time.

\section{Workshop Step 7: A Model for Planning Time}

These concerns provide a bridge for introducing my model for thinking about in-class and out-of-class times (see Figure 4). Unless faculty have such a model, concerns about "coverage" are likely to undermine their assignment-centered course planning and slide them back into the content/lecture/coverage mode.

With Figure 4 on the screen, I explain that, in the traditional lecture/text/coverage model, the teacher lectures the material in the class, and she/he models the thought processes students should follow. But the students are left on their own to do the hardest processessolve the homework problems, draw inferences from data, study for the test, write the paper. The class time is used only to administer the test or to hand in the assignments with which students have struggled in their study time. Then the teacher spends enormous amounts of his or her own time writing responses to this work, trying, without the benefit of face-to-face interaction, to help the student improve his or her higher-order reasoning, analysis, argument, or critique. Teachers wish they could engage in more interactive processing with their students but because students often arrive in class unprepared, and thus 
unable to conduct useful discussion, the teacher is forced to lecture what we call "first-exposure" material which is new to the students.

In the interactive model, all this changes. The students are expected to use their study time for "first exposure." They must read, view tapes, conduct observations and so on, and then prepare writings, graphs, problem solutions, or other work that forces them to wrestle with the material. Then the class is used to help them with the hardest part-the process. Because a great deal of response to students' work now happens in the class-time itself, the teacher need not spend large amounts of out-of-class time responding to that class-preparatory work. (The teacher, of course, will want to respond outside of class to some kinds of student work.)

\section{Workshop Step 8: Case Studies of How Faculty Use Time in Various Disciplines}

To illustrate how this model for use of time would work in an actual situation, you may want to use cases from your own faculty or Breihan's case, below. If you use Breihan's case, call participants' attention to his course skeleton (Figure 3), his first argumentative essay assignment on Burke/Paine/Louis, and the earlier participant-

\begin{tabular}{|c|c|c|}
\hline \multicolumn{3}{|c|}{$\begin{array}{c}\text { FIGURE } 4 \\
\text { A Comparison of the Use of Teacher Time and Student } \\
\text { "Study" Time in Traditional Lecture and in Interactive } \\
\text { Teaching }\end{array}$} \\
\hline & Traditional Lecture & Imteractive Teaching \\
\hline $\begin{array}{l}\text { Clases Time } \\
\text { (includes lab, clinic }\end{array}$ & $\begin{array}{l}\text { First Exposure: } \\
\text { (student first hears or } \\
\text { obeserves facts, ideas, } \\
\text { processes she has not } \\
\text { encountered before) } \\
\end{array}$ & $\begin{array}{l}\text { Process: } \\
\text { (student applied, analyzes, } \\
\text { argues, solves problems, } \\
\text { using firstexposure material) }\end{array}$ \\
\hline Student "Study" Time & Process & First Exposure \\
\hline
\end{tabular}


generated list of what Breihan's students would have to learn if they were to write good argumentative essays in week 6 .

\section{How I Use In-Class Time and Student Study Time for Western Civ}

-John R. Breihan

Based on my analysis of what students would need to learn in order to write sophisticated arguments, I have devised a series of preliminary "exercises" that my students write at home, one for each class session. I give each a minimal grade to ensure completion; reading them usually takes about a minute each, not a substantial addition to my marking load. In return for the time spent, I gain useful insights into how well students are comprehending the course readings. In class I use their "first exposure" work to have them practice more sophisticated skills, such as analyzing evidence and shaping arguments and counterarguments.

A set of preliminary exercises for the first twelve meetings (six weeks) of my Western Civ class is laid out in Figure 5, along with the skills involved in each. Besides short written pieces, the exercises include three classroom "debates" in which groups of students present evidence for various analytical categories or defend assigned positions, while I write on the blackboard the points that each side makes. Students enjoy the give and take of the debates, which is intensified by a small grade given for each point "scored."

Figure 6 is an example of one of these exercises-number 5 on the list above. I base class discussions directly on these exercises. For example, I will begin by asking a student, "What is the issue at stake for today." She or he will respond. Then the next question, again working directly from their writing: "Bishop Bossuet-who was he and when did he write?" The key to this method is to use the students' writing as the basis of in-class interaction. As we move through the questions on the exercise, I try to build upon them for more sophisticated thinking. For example, once we have clarified Bossuet's and Saint Simon's positions, I may ask, "What would they would have to say to each other?" or "What was the most important difference 
between them?" or "Which provides the best evidence?" By the end of this class session, students have had my and their classmates' specific response to their preparatory writings. Thus the writings they brought to class are now out of date. That is why I need only glance over these exercises, awarding points, and perhaps writing a very brief comment. Most of the responding has been done in class.

\begin{tabular}{|c|c|}
\hline \multicolumn{2}{|c|}{$\begin{array}{l}\text { FIGURE } 5 \\
\text { Exercises and Skills for First Six Weeks of Breihan's } \\
\text { Western Civ Course }\end{array}$} \\
\hline Exercises & Skills \\
\hline 1. Summarize textbook chapter & Percoiving authorship; Accurate reporting \\
\hline 2. Paragraph narrating 8 scrambled events & Accurate reporting (chronology); Narration \\
\hline 3. Analysis of eyewitness accounts & $\begin{array}{l}\text { Using standard analytical categories of civil } \\
\text { violence in } 17 \text { th contury }\end{array}$ \\
\hline 4. Classroom competition & $\begin{array}{l}\text { Using analytical categories in analyzing } \\
\text { accounts; Perceiving possible theses }\end{array}$ \\
\hline $\begin{array}{l}\text { 5. Analysis of primary-source accounts of } \\
\text { Louis XIV (seo example below) }\end{array}$ & \begin{tabular}{|c|} 
Percoiving authorship; Percoiving theses; \\
Using sources as evidence
\end{tabular} \\
\hline $\begin{array}{l}\text { 6. Analysis of secondary-source accounts } \\
\text { of Louis }\end{array}$ & $\begin{array}{l}\text { Percoiving authorship; Using sources as } \\
\text { ovidence }\end{array}$ \\
\hline $\begin{array}{l}\text { 7. Worksheet for classroom debate on } \\
\text { Louis XIV-summary of evidence for } \\
\text { assigned position }\end{array}$ & $\begin{array}{l}\text { Perceiving theses; Using sources as } \\
\text { evidence; Stating and defending a } \\
\text { thesis }\end{array}$ \\
\hline 8. Classroom debate on Lovis XIV & $\begin{array}{c}\text { Stating and dofending thesis; Dofending } \\
\text { against counterarguments }\end{array}$ \\
\hline $\begin{array}{l}\text { 9. Second chance work-sheet: what you } \\
\text { might have said in debate }\end{array}$ & $\begin{array}{c}\text { Stating and dofending thesis; Dofending } \\
\text { against counterarguments }\end{array}$ \\
\hline $\begin{array}{l}\text { 10. Burke and Paine on the French } \\
\text { Revolution-views and evidence }\end{array}$ & \begin{tabular}{|c|}
$\begin{array}{c}\text { Percoiving authorship; Percoiving theses; } \\
\text { Using sources as evidence }\end{array}$ \\
\end{tabular} \\
\hline $\begin{array}{l}\text { 11. Debate worksheet "Was Burke or Paine } \\
\text { most correct about the French } \\
\text { Revolution?" }\end{array}$ & $\begin{array}{l}\text { Using sources as evidence; Stating and } \\
\text { dofending thesis; Dofending against } \\
\text { counterarguments }\end{array}$ \\
\hline 12. Classroom dobate & $\begin{array}{l}\text { Using sources as evidence; Stating and } \\
\text { dofending thesis; Dofending against } \\
\text { counterarguments }\end{array}$ \\
\hline
\end{tabular}




\section{Workshop Step 10: Participants Plan Their Own Use of Times and Spaces for Learning}

-Barbara Walvoord

Once participants have read and discussed Breihan's (or your own) case, you will probably want to include illustrations from different disciplines. For example, I often briefly describe the method of a physics professor with whom I have worked. Previously, he was spending most of his in-class time explaining and illustrating the

\section{FIGURE 6 \\ A Sample "Exercise" from Breihan's Class}

Note: This exercise, which students complete at home before class, is based on assigned reading in a problem-oriented text entitted, Great lssues in Western Civilization, by Brian Tierney, Donald Kagan, and L Pearce Williams. The text chapter contains a collection of primary sources, all addressing the issue, "How effective was Louis XIV's rule in ending civil disorder in 17th-century France?" After each question, space is provided for the student's answer.

Name

EXERCISE 5: PRIMARY SOURCES ON LOUIS XIV-due Oct. 7

What is the issue at stake in this chapter of selected readings?

Who was Bishop Bossuet?

When did he write?

What was his position on the issue at stake?

What evidence did he use to back it up?

Who was the Duc de Saint-Simon?

When did he write?

What was his position on the issue at stake?

What evidence did he use to back it up?

Land so on through several more selections] 
principles and concepts of physics and demonstrating problem-solving. Because this was "first exposure" material to the students, they were primarily just struggling to write it all down; they didn't have time to formulate questions. Or they were timid about asking questions, or they thought they understood what he was saying. So, although he frequently asked, "Are there any questions?" he seldom got much response. Outside of class, he assigned homework problems. As students began the problems at home at 2 a.m., they found out they hadn't fully understood the material after all. NOW they had questions, but the professor was unavailable to them for this hardest part of the course-applying the principles to solve problems. In a faculty workshop, he wondered aloud how he might get out of lecturing first-exposure material and help his students in class with the hardest part. Participants asked, "Could you give students a study guide and make them read the book, like Breihan, the historian, does?" "No," said the physicist, "my students can't read the book and then solve the problems, even with a study guide. They need to see concepts illustrated and demonstrated in real time, and they need to see the process of problem-solving worked out step by step, as I talk through why I did this step and then why I did the next step." But there was a way to move the first-exposure out of the classroom: The professor had himself video-taped demonstrating physics principles and problems, and he required the students to see the videotape before they came to class. He might also have used available materials on CD-ROM or on the web. Then, in the class, students gathered in groups of 3 to do the homework problems. The faculty member sacrificed the chance for any interaction during the lecture, but he gained the opportunity for students to replay the taped lecture and to see the tape at a time when they were alert and ready. If he used interactive computer programs, students could make choices and get feedback throughout the demonstration.

What the physicist gained was the ability to help his students in class with the hardest part-the solving of problems. In groups, they taught each other. If the whole group was stuck, they raised their hands, and the professor came over to help them. He had completely reversed his use of class time, moving first exposure to student study time and the hard part-applying the principles - to in-class time. 
Having illustrated how faculty in various disciplines use the model to plan their use of times, you can now ask participants to work on their own course plans. Ask them to return to their list of what their students would need to learn in order to do well on their own first assignment, test, or exam from their course skeleton. Ask them also to return to the list of best methods for enhancing higher-order reasoning (see Figure 1). Keep before them the list of methods that were generated for Breihan's class. If time permits, it's very useful here to spend even more time suggesting possible interactive teaching strategies, so people work with the largest possible repertoire of ideas. You might show videos which demonstrate interactive teaching (e.g., Walvoord \& Williams, 1996). You might have participants, in disciplinary groups, generate wide-ranging lists of teaching strategies that are alternatives to lecture, and discuss the strengths, weaknesses, and characteristics of each method (Bean, 1996, Bonwell \& Eison, 1991, Brown \& Ellison, 1995, and Kurfiss, 1988, are useful).

Then ask faculty to begin laying out their own individual plans for using in-class and out-of-class time in the weeks before their first exam or assignment is due. They might use Breihan's plan as a model (see Figure 5). Refer back to the list of difficulties from the balled-up sheets and tell them it's okay to modify the model to deal realistically with the constraints of their own situations. In this planning they may work together or alone. I keep myself available for consultation.

\section{Workshop Step 11: Address Logistics, Teaching Strate- gies, and Problematic Issues}

If the workshop length is one day or less, you may only have time to give participants a half hour or so to work on their plans, then 20 minutes to share their ideas with a colleague in pairs, and then you'll have to send them on their way. They'll still have lots of questions: How do I do this in large classes? How do I manage students collaborative groups? How do I work with students who speak English as a second language? How do I handle plagiarism? How do I establish criteria for grading? How do I get a reluctant class involved? These might be handled with a bibliography on these various issues or with follow-up brown bag lunches. 
If the workshop is 2-3 days long, you can give participants longer for the initial work on their course plans, say an hour or two, or overnight, or a half day. Ask them to return with a roughed-out plan and with questions they' $d$ like to see discussed in the group. Keep the list of initial concerns and the list of difficulties from the balled-up papers available for their reference.

In a longer workshop, you can also address faculty questions. I ask faculty to call out their questions and I list them on the screen or board. Then I conduct a straw vote to decide which topics we will discuss. Each person may vote for two of the issues on the list. Issues with the highest vote are then scheduled into the remaining workshop time. So, for example, we might spend an hour or two on how to guide collaborative student groups or on how to establish criteria for grading. An alternative is to get a small group working on each question and have the small groups report their best ideas to the larger group.

An alternative plan is to have participants convene in disciplinebased groups with facilitators you have chosen - skilled teachers from those disciplines. In the discipline-based groups, people share the nitty-gritty of applying these principles and models in their own disciplines.

\section{Workshop Step 12: Plan for Follow-Up}

Because this workshop is helping faculty to shape a PROCESS, follow-up is very important. One way I do this is to invite participants to join a group of 3-4 people who agree to meet several times during the ensuing semester to share how their course plans are developing and what is happening as they implement those plans.

\section{Outcomes}

What are the outcomes of such workshops? End-of-workshop participant evaluations have been very positive. Asked to give the workshop a letter grade, participants (averaged over the past six years) have awarded the workshop almost $80 \% \mathrm{~A}$, about $20 \% \mathrm{~B}$, and very few C, D, or F grades. "This workshop has revolutionized my teaching," is a common response. Longer-range outcomes are described by faculty at Whitworth College, where over several years I led a number 
of such workshops (Hunt, 1992). A 1997 study (Walvoord et al.) documents the long-range effects of Whitworth workshops in which, over the past decade, I have increasingly used the models I have presented here. My co-authors and I did not, in that 1997 investigation, directly document changes in the planning process per se, but rather changes in participants' teaching philosophies, teaching methods, and career patterns. However, participant comments and my own observations have increasingly led me to believe that those changes we documented in the 1997 study are closely bound to the integration of the planning process within the workshop and subsequent changes in faculty course planning.

The workshop, then, builds on the assumption that faculty members' course-planning processes are important to teaching and learning. The "assignment-centered" course-planning model provides the basis for faculty action and interaction within the workshop. A model for using time helps faculty to move beyond the concern that they need to use all their in-class time to "cover" the material. These models and the workshop's coherent flow seem to give planning a visibility and importance that faculty have not necessarily recognized. The term "assignment-centered" gives a name to a particular approach to course planning and to teaching and learning. It's a learning-centered and assessment-centered approach. A faculty workshop participant from Criminal Justice reported that she had been groping her way toward such strategies, but the workshop showed her that "there was this school of thought about using these different kinds of techniques." A faculty workshop participant from Communications put it this way: "Naming and renaming [are] extremely powerful. As teachers, we name and rename experiences with our students. As we name and rename with one another and for ourselves, our lives change" (Walvoord et al, 1996, p. 63). Those life changes-in process, in habit, in perspective-are what this workshop seeks to achieve.

\section{References}

Angelo, T. A. (1993, April). A teacher's dozen: Fourteen general, research-based principles for improving higher learning in our classrooms. American Association for Higher Education Bulletin, 46, 3-7, 13. 
Bean, J. C. (1996). Engaging ideas: The professor's guide to integrating writing, critical thinking, and active learning in the classroom. San Francisco: Jossey-Bass.

Bonwell, C. C., \& Eison, J. A. (1991). Active learning: Creating excitement in the classroom (ASHE-ERIC Higher Education No. 1). Washington DC: The George Washington University, School of Education and Human Development.

Brown, D. B., \& Ellison, D. W (1995). What is active learning? In S. R. Hatfield (Ed.), Seven principles in action: Improving undergraduate education. Bolton, MA: Anker.

Chickering, A. W., \& Gamson, Z. F. (1987). Seven principles for good practice in undergraduate education. American Association for Higher Education Bulletin, 39, 3-7.

Hunt, L. L. (1992). Writing across the curriculum. Spokane, WA: Whitworth College. [In-house publication].

Kurfiss, J. G. (1988). Critical thinking (ASHE-ERIC Higher Education No. 2). Washington, DC: American Society for Training and Development.

Schwegler, R., \& Shamoon, L. (1982). The aims and process of the research paper. College English, 44, 817-824.

Stark, J. S., \& Lattuca, L. R. (1997). Shaping the college curriculum: Academic plans in action. Boston: Allyn and Bacon.

Walvoord, B. E. \& Breihan, J. R. (1991). Breihan's history course. In B. E. Walvoord \& L. P. McCarthy (Eds.), Thinking and writing in college: A study of students in four disciplines. Urbana, IL: National Council of Teachers of English. [Note: some copies erroneously list 1990 as copyright date.]

Walvoord, B. E., Hunt, L. L., Dowling, H. F., Jr., \& McMahon, J. D. (1997). In the long run: A study of faculty in three writing-across-the-curriculum programs. Urbana, IL: National Council of Teachers of English.

Walvoord, B. E., \& Anderson, V. J. (in press). Grading for learning, grading for assessment. San Franciso: Jossey-Bass.

Walvoord, B. E., \& Williams, L. (Executive Producers), \& Sanders, M. (Producer). (1996). Making large classes interactive [videotape]. (Available from Lou Olenick, UC Raymond Walters College, Media Service Center, 9555 Plainfield Rd., Cincinnati, OH 45236. Phone: 513-745-5717)

Contact:

Barbara E. Walvoord

Kaneb Center for Teaching and Learning

University of Notre Dame

353 De Bartolo Hall

Notre Dame, IN 46556

(219) 631-9147

(219) 631-8047 FAX

walvoord.1@nd.edu

Jack R. Breihan 


\section{Department of History}

Loyola College in Maryland

4501 N. Charles St.

Baltimore, MD 21210-2699

(410) 617-2427

(410) 617-2832

www.dev.loyola.edu| jbreihan

Barbara E. Walvoord is Director of the John A. Kaneb Center for Teaching and Leaming and (concurrent) Professor of English at the University of Notre Dame, Indiana. She was named 1987 Maryland English Teacher of the Year in Higher Education by the Maryland Council of Teachers of English Language Arts. She has been co-founder and co-director of the Maryland Writing Project (an affiliate of the National Writing Project), and of several other grant-funded projects. Her publications include Thinking and Writing in College: a Study of Students in Four Disciplines (National Council of Teachers of English, 1991), In the Long Run: A Study of Faculty in Three Writing-Across-the-Discipline Programs (NCTE, 1997), and the forthcoming Grading for Learning; Grading for Assessment (Jossey-Bass). For twenty-five years, she has regularly led workshops and done consulting at colleges and universities across the country.

John R. Breihan has taught history at Loyola College in Baltimore since 1977. His courses include the core course on "Modern Civilization," required of all first year students, as well as upper-level courses in British and European history, and historic preservation. Between 1981 and 1987, he was co-director of Loyola's cross-curricular writing program, Empirical Rhetoric, which received a major grant from the National Endowment for the Humanities. Besides collaborating with Walvoord in Thinking and Writing in Colleges, he has published on history pedagogy, British administrative history, and American urban aviation history. During 1996-97 he was Vervialle Fellow in Aviation History at the National Space and Air Museum, Smithsonian Institution. 